\title{
California backs off destruction of records
}

San Francisco. California's state Environmental Protection Agency (Cal-EPA) has suspended a controversial plan to destroy records of dissenting scientific opinions about risk to public health from industrial emissions, chemicals and hazardous waste.

Under a 'records retention policy' introduced last spring, the agency ordered state scientists to destroy research data and internal records that differed from final policy directives on hazard assessment.

The policy would affect documents maintained by the Office of Environmental Health Hazard Assessment, which makes policy on toxicity, carcinogenicity and safety measures related to agricultural chemicals, hazardous wastes and industrial emissions.

Cal-EPA said the policy would foster free exchange of opinion by protecting the identity and views of the scientists involved. But the move was criticized by scientists, environmentalist groups and free-speech advocates, who claim that the policy was designed to do just the opposite - namely to censor debate about public health risks.

Last week, a few hours after a public- interest lawsuit charged the agency with violating the public's right to know about the workings of government, Pete Wilson, the governor of the state, ordered the agency to maintain its records and clarify any confusion over the policy. Cal-EPA agreed not to destroy the documents, but said it would keep them in confidential files.

The Natural Resources Defense Council, the Environmental Law Center and the Society of Professional Journalists had filed a joint suit against the agency in San Francisco. They said Cal-EPA had no legal basis to keep the documents secret, and was violating state public-records laws.

Cal-EPA has the right to keep some documents confidential. But according to Terry Francke, director of the California First Amendment Coalition, a free-speech watchdog group, such action requires the status of the documents to be resolved in court. Destroying documents, he says, subverts California's open-records laws by making such court scrutiny impossible.

Francke argues that the agency's action conflicts with both public access to government operations and the norms of scientific practice. "The presupposition in the development of science is that all information should not only be public, but widely disseminated so discussion can advance on the validity of the research and its findings," he says.

Other protests have come from the California Association of Professional Scientists, a labour union for scientists employed by the state. They argue that scientific integrity would be compromised under the new policy, and that important data on public health would be destroyed.

A memorandum ordering the enactment of the plan instructed state employees to dispose of all documents and other communications prepared during the course of policy formulation "which contain other policy proposals not adopted or reflected in the final decision". Correspondence, electronic messages and scientific data would all be assessed on whether the information they contained was reflected in policy. If in doubt, the documentation was to be destroyed.

Sally Lehrman

\section{Companies cool to tactics of global warming lobby}

London. The Global Climate Coalition (GCC), the US energy lobby group that has challenged some of the main conclusions of United Nations climate scientists about the severity of manmade global warming, has suffered a setback to its lobbying efforts with the resignation of two member companies and the possibility of further withdrawals.

BP America, a subsidiary of British Petroleum, and the Arizona Public Service Company, a Phoenix-based electric power utility, are pulling out of the group, which earlier this year accused scientists working for the Intergovernmental Panel on Climate Change (IPCC) of distorting the conclusions of a key report in order to over-emphasize the role of human activities in climate change (see Nature 383, 287; 1996) .

Klaus Kohlhase, head environment adviser at BP headquarters in London, says that BP felt its interests in the United States were not best represented by remaining in the coalition. But BP, he says, will stay a member of the International Climate Change Partnership, an alternative industry lobby group which he describes as "a more moderate and conciliatory" body.

Mark De Michele, chief executive of the Arizona Public Service Company, partly shares that sentiment. "Global climate change is a serious problem and we need to take steps to deal with it," says De Michele, one of the architects of a Clinton administration-backed initiative to persuade power utilities voluntarily to reduce greenhouse gas emissions. "I was concerned that to continue to attack the science - which the GCC is basically doing - is not the way forward."

Representatives of environmentalist groups, such as the US Climate Action Network, the Natural Resources Defense Council and Greenpeace, say that the resignations are a significant development. Paul Horsman, head of oil campaigns at Greenpeace, claims that some members of the energy industry are realizing that the GCC has lost credibility and are re-grouping around other organizations, such as the climate change partnership and the Business Council for a Sustainable Energy Future.

But Bill O'Keefe, president of GCC and a vice-president of the American Petroleum Institute, shrugs off the resignations. "We're adding members, not losing them," he says. "We have eight to ten new board members, and are still the leading business voice in climate change."

Both BP and the Arizona Public Service Company, says GCC's executive director John Shlaes, were 'general' members, a category he describes as "an educational forum". 'Board' membership, on the other hand, entitles companies to influence GCC policy, and costs US $\$ 20,000$ annually (general members pay US\$2,500).

This summer, the GCC mounted a vociferous campaign to contest a report written by scientists working for the IPCC, which had been re-edited just before publication. The GCC claimed that the alterations amounted to "scientific cleansing". The scientists said the changes were necessary to clarify parts of the text that had earlier confused policy-makers. The ensuing war of words caught the attention of Republican members of the US Senate, who convened a series of hearings into the matter.

Several GCC member companies are understood to have been uneasy about the organization's aggressive tactics. And in July, a senior US administration official weighed in by indirectly referring to the GCC as "naysayers and special interests bent on belittling, attacking and obfuscating climate change science", in a speech to the annual conference of the climate convention in Geneva (see Nature 382, 287; 1996).

But the withdrawal of the Arizona Public Service Company is also believed to have been influenced from another quarter - the Interfaith Center on Corporate Responsibility, an association of institutional investors representing US churches and other religious-based investments. The centre, which claims to represent combined investments of US $\$ 70$ billion, has asked each GCC member company - where its affiliates are shareholders - to resign from the coalition.

Ariane van Buren, director of the centre's environment programme, says the GCC should not be allowed to do further harm to the process of dealing with global climate change. "In no case should [a member] company allow its name to be associated with any additional GCC activities that distort the facts." Companies, she says, should join "responsible business coalitions".

Ehsan Masood 